$551.508 .952: 551.521$

\title{
On Various Methods of Measuring the Vertical Distribution of Atmospheric Ozone (I)
}

\author{
- Optical Type Ozonesonde - \\ by \\ J. Kobayashi, M. Kyozuka \\ Meteorological Research Institute, Tokyo \\ and \\ H. Muramatsu \\ Aerological Observatory, Tateno \\ (Received August 22, 1966)
}

\begin{abstract}
An optical method is described for the measurement of the vertical distribution of atmospheric ozone in the upper atmosphere by means of the sounding balloon.

The determination of the amount of ozone in the air above the instrument is done by measuring the intensities of two beams of the sunlight and calculating their ratio in intensity: one corresponds to the light intensity at the wavelength of $3050 \AA$ and the other to that at the wavelength of $3400 \AA$. The half-width of each spectrum is about $270 \AA$ and $120 \AA$ respectively.

The essential part of the instrument consists of a light collector, optical filters, a photocell, an a.c. amplifier with a chopping circuit and a telemetering system. The measured values corresponding to each spectrum are sent to the ground stations together with the other meteorological elements such as air temperature and pressure by use of the so-called audio-frequency type transmitter.
\end{abstract}

Two examples of flight results are presented and discussed.

\section{Introduction}

To solve such interesting problems as the breakdown of the winter polar vortex and the reversed seasonal temperature variation, it is necessary to know the fundamental physical processes affecting the energetics and motions in the stratosphere and mesosphere. In these regions, ozone is significantly involved in the above-mentioned processes.

It must be stressed that synoptic observations of the vertical distribution of atmospheric ozone are very important for the investigation of the general circulation and the radiative balance of the atmosphere. The greatest help is likely to be offered 
by the development of ozone sondes, because they make direct and detailed measurements of the vertical distribution of atmospheric ozone.

Many devices have been developed since 1921. The most suitable for measurements below $30 \mathrm{~km}$ seems to be the balloon-borne systems. These are, however, still in the developmental stage. On the other hand, in the region above $30 \mathrm{~km}$, Umkehr measurements and rocket and satellite measurements, using spectroscopic techniques, have been useful. In order to extend the network of ozone observation and to solve various research problems in the physics of the upper atmosphere, it is in particular important that the instruments be more reliable and standardized.

If we classify all the current ozone devices on the basis of the operational principle only, they will fall into two broad classes: one based on the optical method and the other on the chemical method. The merit of the optical method lies in being available for the research of the ozone layer above $20 \mathrm{~km}$. The chemical system is expected to be useful for the observation below $30 \mathrm{~km}$.

Various optical types of ozonesondes have already been developed, (BANCAREL et al, 1964; Coblenz et al, 1939; Kobayashi et al, 1965; Krueger, 1964; Kulcke and Paetzold, 1957). The device developed by Paetzold et al. in Germany, is a typical one. In their instrument, it has been pointed out that, the scatter of measured values being too large, the vertical profile of atmospheric ozone often becomes very ambiguous. But, taking into consideration the fact that this method possesses a high reliability in measuring the ozone densities above the height of $20 \mathrm{~km}$, an optical type ozonesonde with high fidelity in indication has been developed in Japan since 1960.

\section{Principles of the optical ozonesonde}

The operating principles of the instrument are the same as are followed by Paetzold et al. in Germany. They utilize the light absorption of ozone in the ultraviolet region for the measurement of the amount of ozone above the instrument.

The intensity of an ultraviolet light injected on the photocell, $I_{U}$, and that of a blue light, $I_{B}$, are shown as follows:

$$
I_{U}=\int_{\lambda_{1}}^{\lambda_{2}} I_{0 \lambda} T_{\lambda} S_{\lambda} \cdot 10-\beta_{\lambda} m \sec z-\alpha_{\lambda} X \sec z d \lambda
$$

and

$$
I_{B}=\int_{\lambda_{3}}^{\lambda_{4}} I_{0 \lambda} T_{\lambda} S_{\lambda} \cdot 10-\beta_{\lambda} m \sec z d \lambda,
$$

where $\quad I_{0 \lambda}:$ Intensity of sunlight,

$T_{\lambda}$ : Transmissivity of the filter,

$S_{\lambda}$ : Sensitivity of the photocell,

$\alpha_{\lambda}$ : Absorption coefficient of the ozone molecule, $\left(\mathrm{cm}^{-1}\right)$,

$X$ : Amount of ozone above the instrument, $(\mathrm{cm})$,

$\beta_{\lambda}$ : Scattering coefficient of the air molecule,

$m$ : Amount of the air above the instrument, and

$z$ : Zenith distance.

The zenith distance is given by 


$$
\frac{1}{\sec z}=\cos z=\cos t \cos \phi \cos \delta+\sin \phi \sin \delta,
$$

where

$$
\begin{array}{ll}
t: & \text { Hour angle, } \\
\delta: & \text { Solar declination angle and } \\
\phi: & \text { Latitude. }
\end{array}
$$

Now, let us replace the product $I_{0 \lambda} T_{\lambda} S_{\lambda}$ with a selective function $F_{\lambda}$ and each intensity of injected light with the output signal, $E$, then Eqs. (1) and (2) are rewritten by

$$
E_{U}=\int_{\lambda_{1}}^{\lambda_{2}} C_{U} \cdot F_{\lambda} \cdot 10-\alpha_{\lambda} X \sec z-\beta_{\lambda} m \sec z d \lambda
$$

and

$$
E_{B}=\int_{\lambda_{3}}^{\lambda_{4}} C_{B} \cdot F_{\lambda} \cdot 10-\beta_{\lambda} m \sec z d \lambda
$$

where $C_{U}$ and $C_{B}$ are the constants of the instrument.

In order to simplify the computation, it is necessary to replace both $\alpha_{\lambda}$ and $\beta_{\lambda}$ with the effective values, $\bar{\alpha}$ and $\bar{\beta}$, which are defined as follows:

$$
\bar{\beta}_{U}=-\frac{1}{m \sec z} \log \frac{\int_{\lambda_{1}}^{\lambda_{2}} F_{\lambda} \cdot 10^{-\alpha_{\lambda} X \sec z-\beta_{\lambda} m \sec z d \lambda}}{\int_{\lambda_{1}}^{\lambda_{2}} F_{\lambda} \cdot 10^{-\alpha_{\lambda} X \sec z} d \lambda},
$$$$
\bar{\beta}_{B}=-\frac{1}{m \sec z} \log \frac{\int_{\lambda_{3}}^{\lambda_{4}} F_{\lambda} \cdot 10-\beta_{\lambda} m \sec z d \lambda}{\int_{\lambda_{3}}^{\lambda_{4}} F \lambda d \lambda},
$$

$$
\begin{aligned}
\bar{\beta}_{U}=\frac{\int_{\lambda_{1}}^{\lambda_{2}} F_{\lambda} \cdot 10^{-\alpha_{\lambda} X \sec z \cdot \beta_{\lambda} \cdot d \lambda},}{\int_{\lambda_{1}}^{\lambda_{2}} F_{\lambda} \cdot 10^{-\alpha_{\lambda} X \sec z} d \lambda}, & \text { at } m \sec z=0 \\
\bar{\beta}_{B}=-\int_{\lambda_{3}}^{\lambda_{4}} F_{\lambda} \cdot \beta_{\lambda} d \lambda & \text { at } m \sec z=0
\end{aligned}
$$$$
\text { at } m \sec z=0
$$

$$
\begin{aligned}
& \bar{\alpha}=-\frac{1}{X \sec z} \log \frac{\int_{\lambda_{1}}^{\lambda_{2}} F_{\lambda} \cdot 10^{-\alpha_{\lambda} X \sec z d \lambda}}{\int_{\lambda_{1}}^{\lambda_{2}} F_{\lambda} \cdot d \lambda} \quad \text { and } \\
& \bar{\alpha}=\frac{\int_{\lambda_{1}}^{\lambda_{2}} F_{\lambda} \cdot \alpha_{\lambda} \cdot d \lambda}{\int_{\lambda_{1}}^{\lambda_{2}} F_{\lambda} \cdot d \lambda} \\
& \text { at } X \sec z=0,
\end{aligned}
$$

where suffixes, $U$ and $B$, correspond to the ultraviolet light and to the blue. 
Putting these relations into Eqs. $(1)^{\prime}$ and $(2)^{\prime}$, the relation between the intensity of the ultraviolet light and that of the blue is shown as follows:

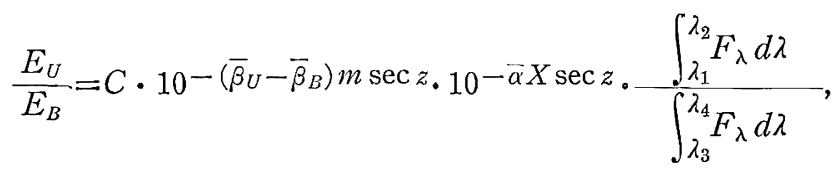

where $C$ is the ratio of $C_{U}$ to $C_{B}$.

Then, Eq. (7) can be rewritten as follows :

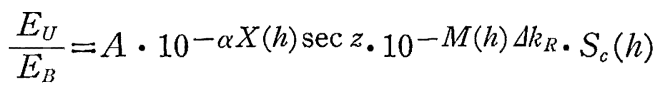

$$
\begin{aligned}
& A=C \frac{\int_{\lambda_{1}}^{\lambda_{2}} F_{\lambda} d \lambda}{\int_{\lambda_{3}}^{\lambda_{4}} F_{\lambda} d \lambda} \\
& \alpha=\bar{\alpha} \\
& \Delta K_{R}=\bar{\beta}_{U}-\bar{\beta}_{B} \\
& M(h)=m \sec z=\frac{P(h)}{P_{0}} \sec z=\frac{P(h)}{1013} \cdot \sec z .
\end{aligned}
$$

In Eq. (8), $S_{c}(h)$ is a correction factor for the scattering skylight, $h$ the height of the instrument and $P$ the pressure at the height $h$.

Provided that the absorption coefficient of ozone, the scattering coefficient of the air, the skylight factor, the shape of the spectrum and the constant of the instrument are known, the amount of ozone at height $h$ will be given by calculating the ratio of the two sets of measured values as shown in Eq. (7).

In order to obtain the good accuracy, the spectral regions of interest should be isolated by use of narrow-band optical filter systems. Besides, it is necessary to know the height variation of skylight and to devise an omnidirectional light collector. Furthermore, several factors in the design of the instrument should be taken into consideration, such as accuracy, reliability, cost, ease of calibration and field use, and mechanical strength.

In the evaluation, it is assumed that the results with regard to the skylight factor which were obtained by Kulcke and PAETzold (1961) are correct and that both the absorption coefficient and the scattering coefficient are well-known.

\section{Balloon-borne instrument}

The essential part of the instrument consists of an omnidirectional light collector, a broad-band color filter, four transparent filters, a photocell and an a.c. amplifier with a mechanical chopping system, sensors for measuring meteorological elements such as temperature and pressure, and a telemetering system. Fig. 1 shows the schematic diagram of the instrument. 


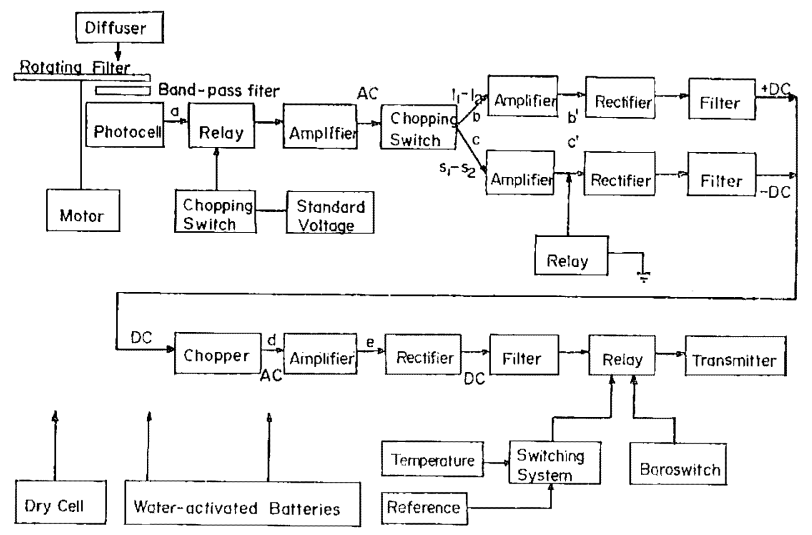

Fig. 1. Block diagram of the ozonesonde.

\section{(i) Light collector}

Sunlight is collected by using a flask-shaped light collector, $50 \mathrm{~mm}$ in diameter made of opaque quartz glass, $0.5 \mathrm{~mm}$ in thickness or methacrylic acid ester resin, 1.0 $\mathrm{mm}$ in thickness. Fig. 2 shows the transmissivity of various kinds of materials within the wavelength range from 275 to $400 \mathrm{~m} \mu$. Such materials as cellophane (curve $C$ in Fig. 2), Mylar (curve $D$ ), and soda-glass (curve $E$ ) do not meet the aim of our in-

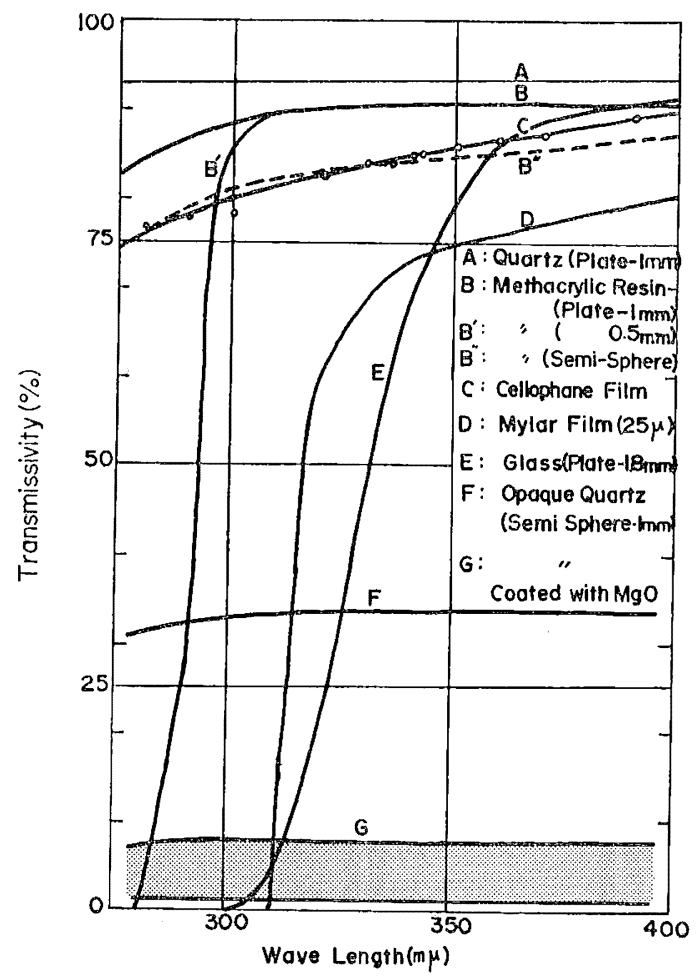

Fig. 2. Transmissivities of various kinds of materials. 
strumentation, but it can be seen that quartz glass (curve $A$ ), methacrylic resin (curve $B$ ) and opaque quartz glass (curve $F$ ) are all useful.

The inner side of the collector is smoked with $\mathrm{MgO}$ particles. Its transmissivity is about $2 \%$ to $8 \%$ throughout the wavelength range from $2900 \AA$ to $5000 \AA$, as shown by curve $G$ in Fig. 2. In practice, the smoking is done so as to obtain the transmissivity below $2 \%$ with the trial-and-error method.

The relative error caused by the swinging of the instrument is estimated to be about $\pm 5 \%$ on all the directions. Fig. 3 shows the variation in transmissivity of the light collector dependent on the elevation angle. With reference to the azimuth direction, only a very slight difference in transmissivity can be found. Then, judging from the fact that the swinging angle to the vertical does not exceed 20 degrees, the fluctuation in indication caused by the swinging may be within at most $\pm 2 \%$.

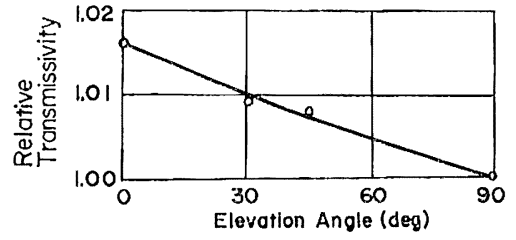

(a)

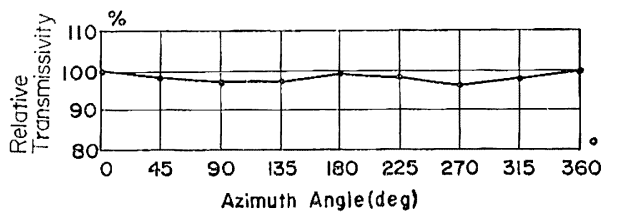

(b)

Fig. 3. Directional characteristics of the light collector.

\section{Broad-band filter}

A broad-band colour filter is placed at the front of a photocell. This filter isolates the spectral region of interest $(2700 \AA$ to $4300 \AA$ ) and serves to impede the entrance of light unnecessary for the measurement into the detecting system, though this possesses a finite transmission in the range of wavelength longer than $6500 \AA$, as shown in Fig. 4. On the other hand, the sensitivity of the photocell used becomes negligibly small in this longer wavelength range. Therefore, the whole measuring system is not affected by the above-mentioned unfavourable factor.

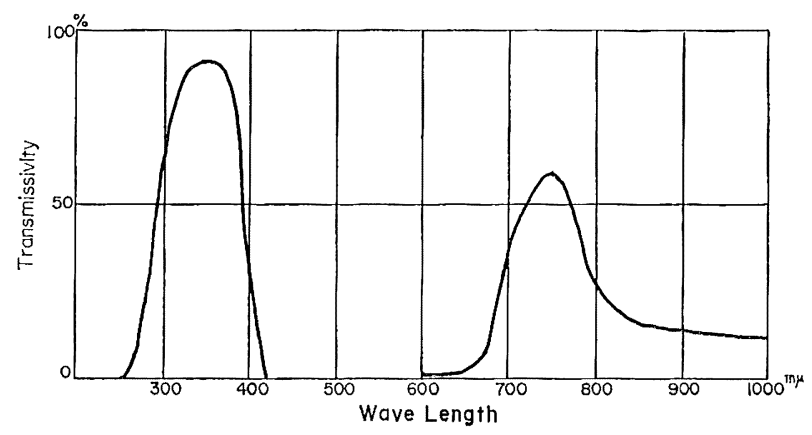

Fig. 4. Transmissivities of the band-pass colored filter.

In practice, a filter $0.6 \mathrm{~mm}$ in thickness is used. Its polished surface is made clean before use. 


\section{(ii) Filters}

In order to pick up two spectra of interest, four filters are placed on a metal frame which is rotated in front of a photocell by a small motor. The revolution rate is about $30 \mathrm{cps}$. The transmissivities of these filters are shown in Fig. 5 and the specifications in Table 1.

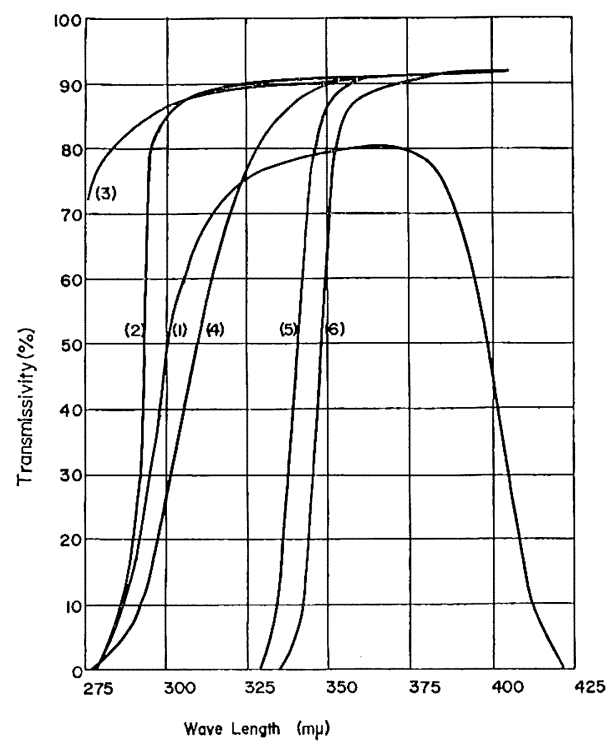

Fig. 5. Transmissivities of the filters used.

Table 1.

\begin{tabular}{c|c|c|c}
\hline \hline $\begin{array}{c}\text { No. of } \\
\text { Filter }\end{array}$ & Thickness & Material & $\begin{array}{c}\text { Wavelength } \\
\text { corresponding to } \\
50 \% \text { transmissivity }\end{array}$ \\
\hline 1 & $0.6 \mathrm{~mm}$ & UV colored glass & $3000,3950 \AA$ \\
2 & 0.5 & Methacrylic resin & $2925 \AA$ \\
3 & 1.0 & " & 2650 \\
4 & 0.5 & $\begin{array}{l}\text { Soda glass } \\
\text { Methacrylic resin } \\
\text { (specially made) }\end{array}$ & 3100 \\
6 & 1.8 & " & 3400 \\
\hline
\end{tabular}

No. 1 in Fig. 5 shows the transmissivity of the above-mentioned band-pass filter. The filter, No. 2 in Fig. 5, is used together with the filter of No. 1 to get the sharp cutoff in the ultraviolet range.

Two pairs of filters, one pair composed of No. 3 and No. 4 and the other of No. 5 and No. 6, are mounted on the same rotating frame. The two filters of the pair are placed to face each other and each filter is so arranged as to be like a sector forming a quarter part of a circular plate. Each spectrum of interest needed for the ozone measurement is made by picking up the difference of transmissivity in each pair of filters, for instance between No. 3 and No. 4. 
As to the variance in transmissivity of each kind of filter, the average transmissivity, $\bar{\tau}$, and the average absolute deviation, $|\bar{\delta} \tau|$, in transmissivity are shown in Table 2. The random sampling number of the same kind of filters is 10 respectively.

Table 2.

\begin{tabular}{|c|c|c|c|c|c|c|c|c|}
\hline Wavelength & Band-p & filter & Filter & No. 2 & $\begin{array}{l}\text { A pair } \\
\text { No. } 3 \text { a }\end{array}$ & $\begin{array}{l}\text { filters, } \\
\text { No. } 4\end{array}$ & $\begin{array}{l}\text { A pair } \\
\text { No. } 5 \text { a }\end{array}$ & $\begin{array}{l}\text { filters, } \\
\text { No. } 6\end{array}$ \\
\hline \multirow{2}{*}{$(\AA)$} & \multicolumn{2}{|c|}{$(\%)$} & \multicolumn{2}{|c|}{$(\%)$} & \multicolumn{2}{|c|}{$(\%)$} & \multicolumn{2}{|c|}{$(\%)$} \\
\hline & $\bar{\tau}$ & $|\overline{\delta \tau}|$ & $\tau$ & $|\bar{\delta} \tau|$ & $\bar{\tau}$ & $|\overline{\delta \tau}|$ & $\bar{\tau}$ & $|\overline{\delta \tau}|$ \\
\hline 2700 & & & & & 60.95 & 4.04 & & \\
\hline 2800 & 0.19 & 0.05 & 0.14 & 0.08 & 77.08 & 1.23 & & \\
\hline 2900 & 15.09 & 0.61 & 19. 24 & 4. 12 & 76.81 & 1.19 & & \\
\hline 3000 & 49. 10 & 0.88 & 85.44 & 0.75 & 62.30 & 0.70 & & \\
\hline 3100 & 66.14 & 0.87 & 88.67 & 0.44 & 38.83 & 0.51 & & \\
\hline 3200 & 73.66 & 0.57 & 89.52 & 0.44 & 18.32 & 0.54 & & \\
\hline 3300 & 77.11 & 0.85 & 90.15 & 0.61 & 7.66 & 0.46 & 0.66 & 0.12 \\
\hline 3400 & 79.08 & 0.93 & 90.31 & 0.51 & 2.38 & 0.34 & 40.58 & 1. 18 \\
\hline 3500 & 80.15 & 0.94 & 91.25 & 0.50 & 0.30 & 0.28 & 14.21 & 0.73 \\
\hline 3600 & 80.65 & 0.91 & 90.90 & 0.51 & -0.50 & 0.20 & 2.81 & 0.35 \\
\hline 3700 & 80.57 & 0.84 & 91.52 & 0.53 & & & 1.28 & 0.12 \\
\hline 3800 & 78.20 & 0.72 & 91.15 & 0.64 & -0.31 & 0.25 & 0.87 & 0.48 \\
\hline 3900 & 68.93 & 0.90 & 91.48 & 0.58 & & & 0.37 & 0.47 \\
\hline 4000 & 46.97 & 0.89 & 91.63 & 0.40 & -0.14 & 0.26 & 0.02 & 0.40 \\
\hline
\end{tabular}

Such errors as shown in Table 2, which are due to difference in transmissivity from the average, should be taken into consideration in evaluating the ozone densities in the upper atmosphere accurately. In this case, the temperature effect on transmissivity should also be taken into consideration.

Fig. 6 shows the temperature coefficient of each filter at various transmissivities. Several experiments on the transmissivities of filters to be used were made at the temperature range from $-10^{\circ} \mathrm{C}$ to $+40^{\circ} \mathrm{C}$.

The temperature coefficient is here defined by $1 / \tau \cdot d \tau / d T$, where $T$ is the ambient temperature, ${ }^{\circ} \mathrm{C}$, surrounding the test piece. The temperature coefficient decreases with the decrease in transmissivity and

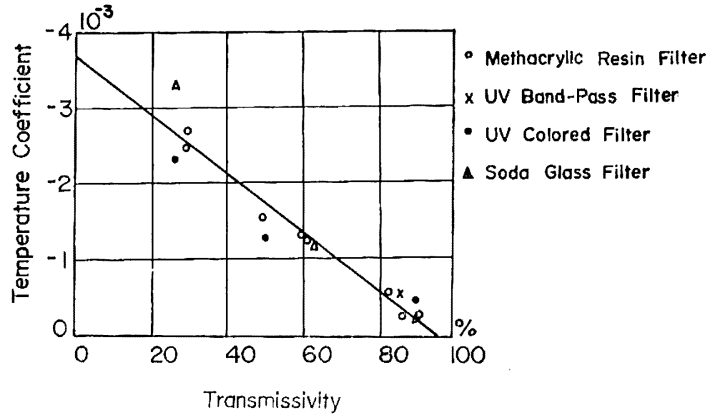

Fig. 6. Maximum temperature coefficient of various kinds of filters. the transmissivity increases with the decrease in ambient temperature. In practice, variation in ambient temperature does not exceed $20^{\circ} \mathrm{C}$ and the temperature of the used filter itself does not follow its am- 
bient temperature owing to its large heat capacity. Therefore, for simplification in evaluation procedure, this effect is put out of consideration, but it is desirable to pay some attention to this problem.

\section{(iii) Selective function}

Sunlight is received with an Sb-Cs photocell. As the intensity of light received by the photocell varies with the transmissivity of the rotating filter facing the photocell, the photocurrent varies in tiers. After the output of the photocurrent is amplified, difference in the current is taken up corresponding to the difference in transmissivity of a pair of filters by means of a mechanical chopping system. One pair of filters is selected from the four filters by use of a sequence switching system. Thus, two spectra of interest are distinguished. One of them corresponds to the wavelength of $3050 \AA$ and the other to that of $3400 \AA$. The half width of the spectra is about $270 \AA$ and $120 \AA$ respectively. Fig. 7 shows two selective functions defined

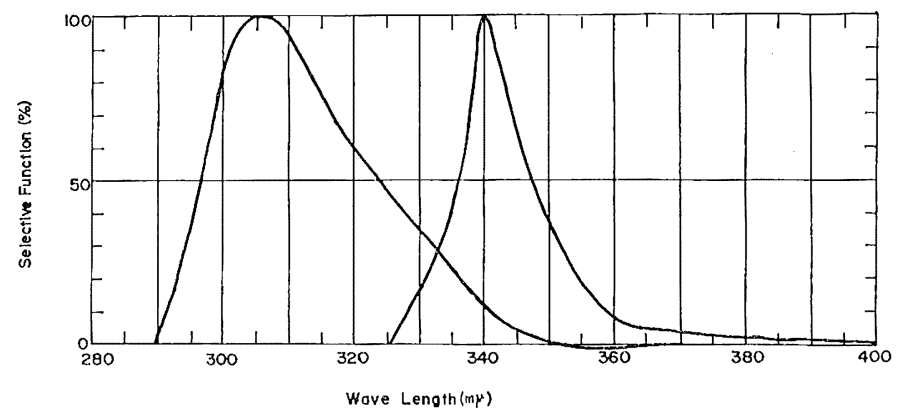

Fig. 7. Selective function.

by the product of the difference in transmissivity of a pair of filters, the intensity of sunlight in the top of atmosphere and the sensitivity of the photocell at various wavelengths, which are presented in relative unit (see Column $F$ in Tab. 3). The magnitude of the wing of each spectrum depends on the difference in the maximum transmissivity of a pair of filters. The medium wavelength of each spectrum is slightly shifted to the shorter wavelength region with decrease in temperature owing to the temperature effect on the transmissivity of the filter.

Fig. 8 shows the sensitivity of the photocell used. The sensitivity slightly varies over the practical working region, but this photocell possesses high responding photocurrent characteristics, compared with the other singlestage vacuum photocells such as a $\mathrm{Mg}$ photocell, etc.

\section{(iv) Amplifier}

The amplifier is basically a transistorized ac system with a great deal of feedback for stability. Fig. 1 shows the block diagram of this system,

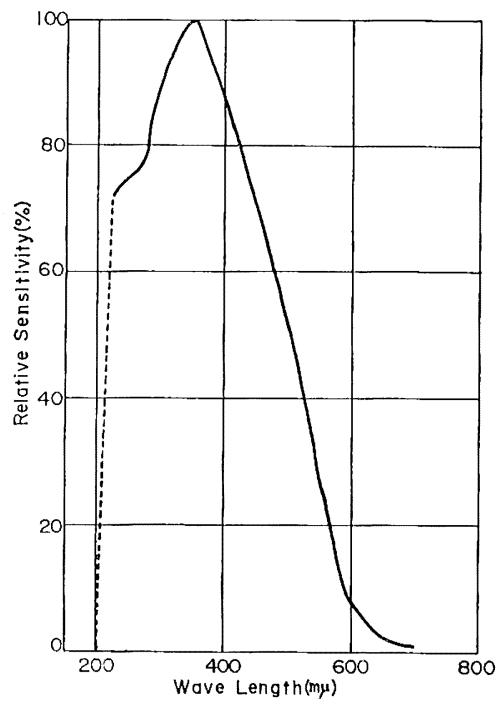

Fig. 8. Response curve of an $\mathrm{Sb}-\mathrm{Cs}$ photocell. 
and Fig. 9 shows the wave pattern at each stage of the amplifier, (see Fig. 1).

The signal source is coupled to the input with a capacitor and amplified. The wave form of the signal is in a four-stepped shape, as shown in line (a) of Fig. 9. The letters, $s$ and 1, show the input signals corresponding to the shorter wavelength spectrum and the longer respectively. Subscript 1 corresponds to the output signal through the filter with higher transmissivity of one pair of filters and subscript 2 to that of the filter with lower transmissivity. At the next stage, each output signal is selected by a sequence switching system to pick up the difference in each pair of output signals, as shown respectively in lines, (b) and (c), of Fig. 9, whose magnitude corresponds to the difference in transmissivity of a pair of filters. Each difference is transformed into the difference in voltage and picked up by a chopping

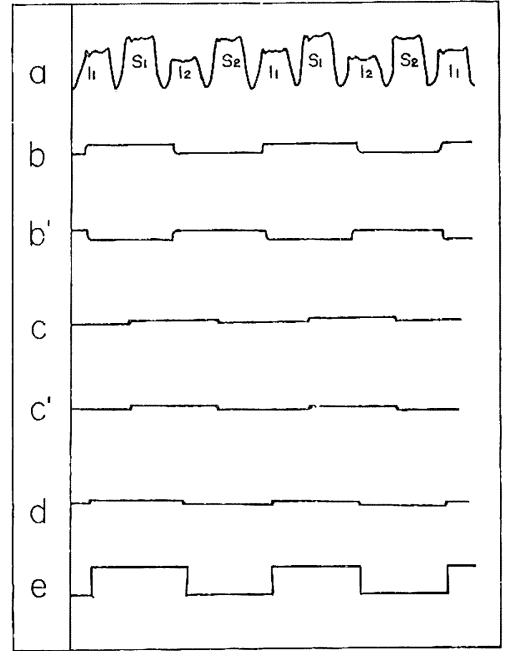

Fig. 9. Wave form of the signal at each stage of the amplifier. system. At that time, each signal is amplified in a rectangular form, while the phase of the output voltage for the longer spectrum is turned over, as shown in line $\left(b^{\prime}\right)$. After that, several choices are permitted in combining these two signals with the aid of the sequence switching system. In our system, two signals are picked up: one corresponds to the intensity of the spectrum at a longer wavelength region, and the other corresponds to the difference in intensity between the two spectra. In order to get the former spectrum, the output signal corresponding to the latter is shut out by the operation of the sequence switching system and replaced by zero signal, while the difference is obtained by adding the two respective dc output signals directly. To do that, each output signal is filtered and converted to dc before selection. Each filtered dc signal made in accordance with the sequence switching program is chopped by a chopper, which is shown in line(d), amplified, as shown in line(e), and then rectified. Thus the audio-frequency of the modulator is controlled by the magnitude of this output dc signal. Fig. 10 shows the circuit diagram of the amplifier. The gain of the amplifier is about $50 \mathrm{db}$.

The accuracy of the amplifier mainly depends both on the stability of applied voltage and on the effect of ambient conditions on the characteristics of the circuit parameters such as temperature, humidity, etc. Fig. 11 shows the effect of the change in applied voltage on the output signal at various constant input signals.

The amplifier is activated by two dry cells: one is a $45 \mathrm{~V}$ cell and the other a $9 \mathrm{~V}$. The left-hand figure shows the results on the effect of changes in voltage of a substituted $9 \mathrm{~V}$ cell and the right-hand figure those on that of the substituted $45 \mathrm{~V}$ cell. The former slightly affects the magnitude of the output signal, but no effect due to the latter can be found. In practice, the drop in voltage mainly depends on the fall in temperature of the used cell itself. By the way, all parts of the amplifier are kept in a container, which is insulated from the outdoor air, to avoid the temperature effect on the circuit parameters. Furthermore, the container is warmed by 


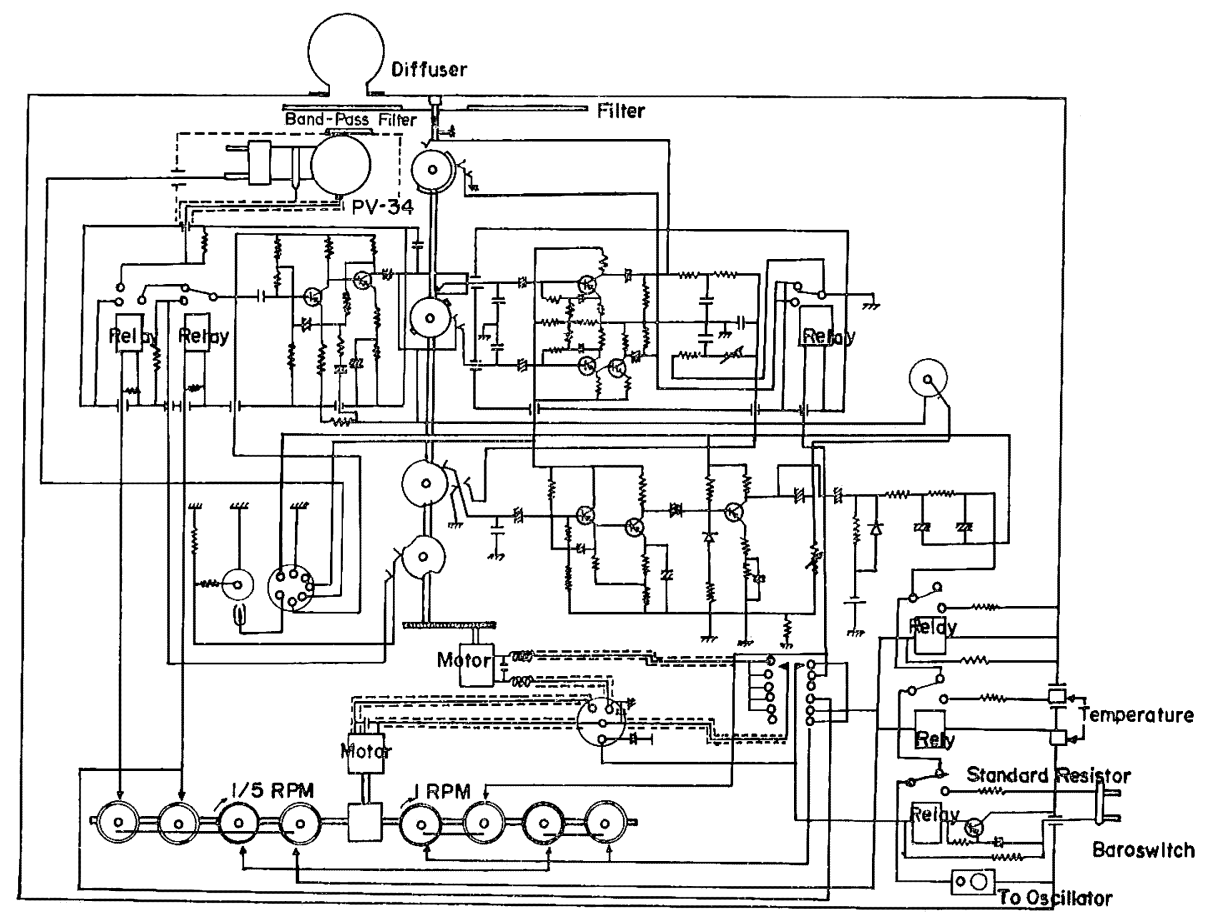

Fig. 10. Circuit diagram of the ozonesonde.
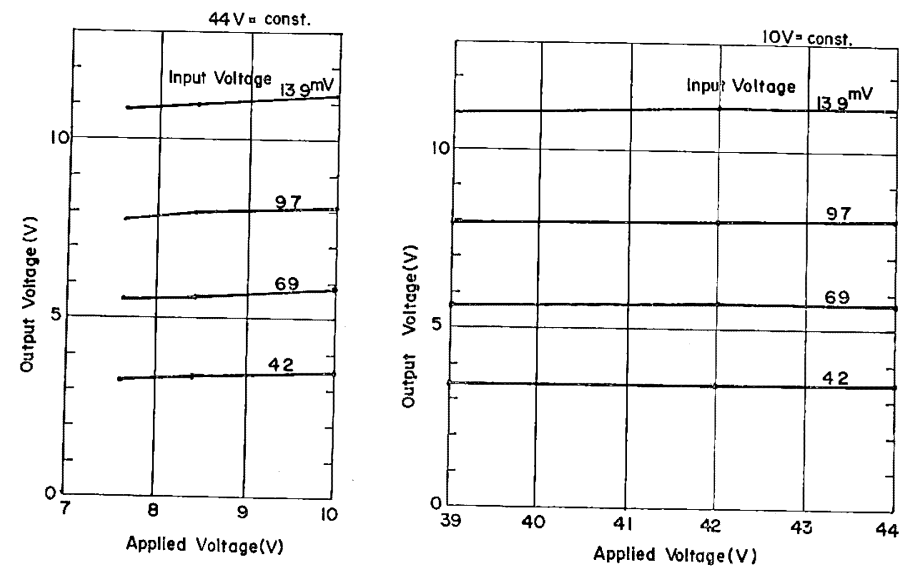

Fig. 11. Effect of the change in voltage applied to the amplifier on the output.

utilizing the excess of heat originated in the water-activated batteries for a transmitter. Therefore, no remarkable drop in voltage can be expected. According to several flight results, the temperature fall was less than $20^{\circ} \mathrm{C}$ and the minimum temperature was always above $15^{\circ} \mathrm{C}$, as shown in Fig. 12 .

However, in order to watch the shift of the sensitivity of the amplifier, standard voltages, $70 \mathrm{mV}$ and $0 \mathrm{~V}$, are occasionally applied to the input of the amplifier in place of the output of the photocell by help of the sequence switch. 


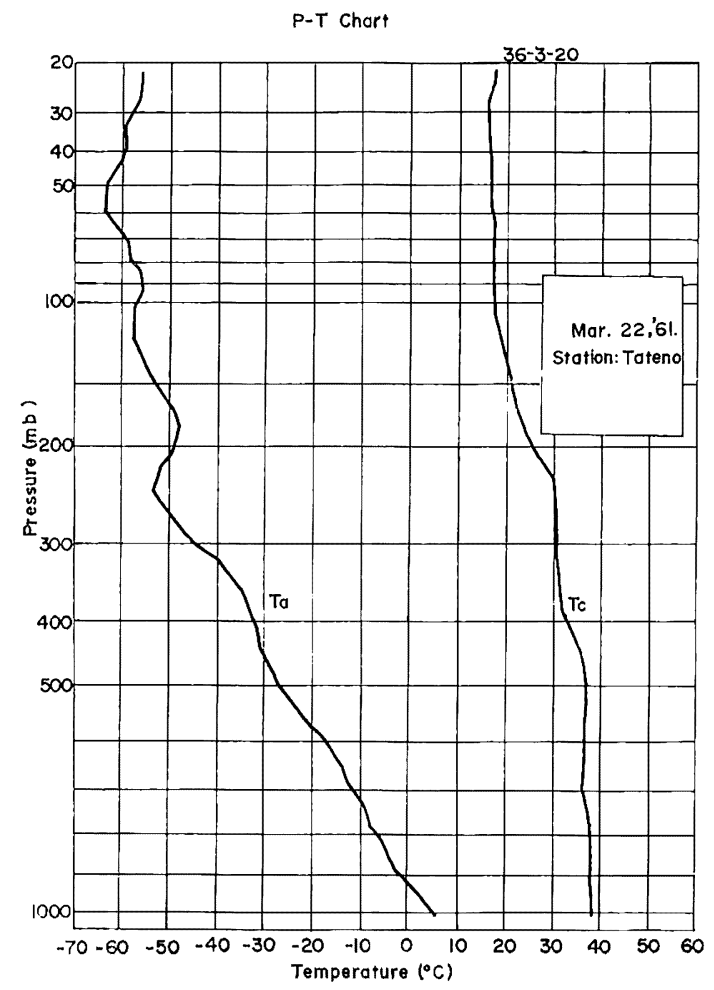

Fig. 12. Temperature profile; $T_{c}$ : Temperature in the container.

$T_{a}:$ Air temperature.

\section{(v) Transmitter}

The transmitter used is almost the same as that used in routine work. The frequency of the transmitter is $1680 \mathrm{MC}$. The audio-frequency of the modulator varies from $50 \mathrm{cps}$ to $180 \mathrm{cps}$ in accordance with the intensity of input signal from $0 \mathrm{~V}$ to $150 \mathrm{mV}$.

The other meteorological variables such as pressure are measured by use of a baroswitch. Temperature also can be measured with a thermistor.

The program of a sequence switching system is as follows:

Information on the spectrum of $3400 \AA \quad$ : $30 \mathrm{sec}$, and

Information on the difference in intensity : $30 \mathrm{sec}$.

between the two spectra,

$3050 \AA$ and $3400 \AA$

The reference mark (a fixed resistor) is inserted in the grid circuit of the modulator by means of a baroswitch. The zero mark and the standard of the amplifier are alternately switched into the modulator every five minutes in place of the signal on the intensity of the spectrum of $3400 \AA$.

Ground equipments consist of the following :

(1) D-55-A rawin set, and

(2) Receiving set and recorder. 


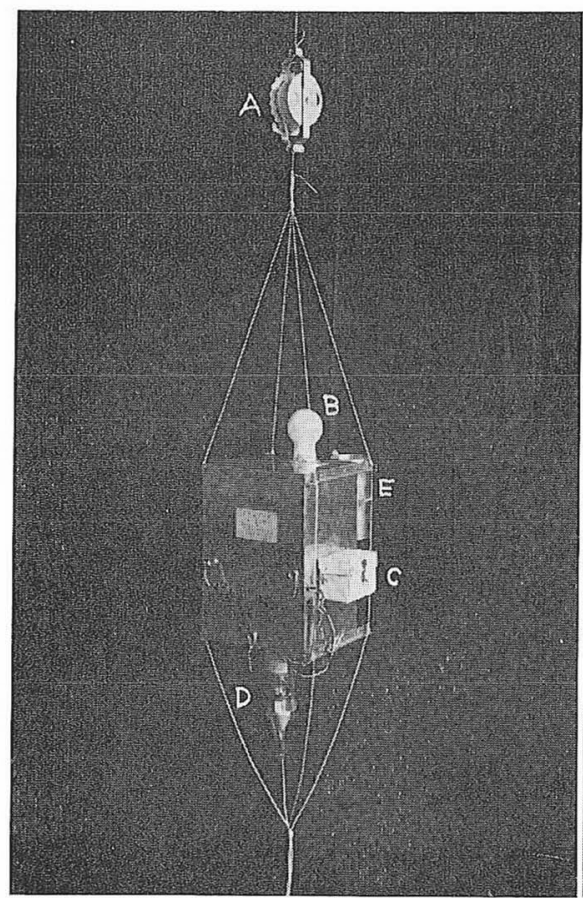

Photo. 1. Appearance of the opticaltype ozonesonde.
A: Reel
B: Light collector
C: Baroswitch
D: Transmitter
E: Duct

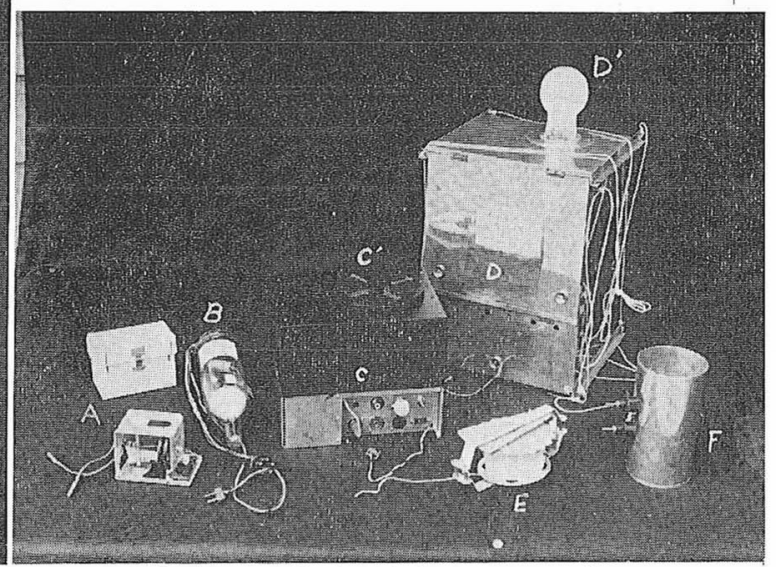

Photo. 2. Parts of the ozonesonde.

A: Baroswitch and its container

B: Transmitter

C: Amplifier

$\mathrm{C}^{\prime}$ : Rotating filter frame

D: Container

$\mathrm{D}^{\prime}$ : Light collector

E: Reel

F: Duct for temperature measurement

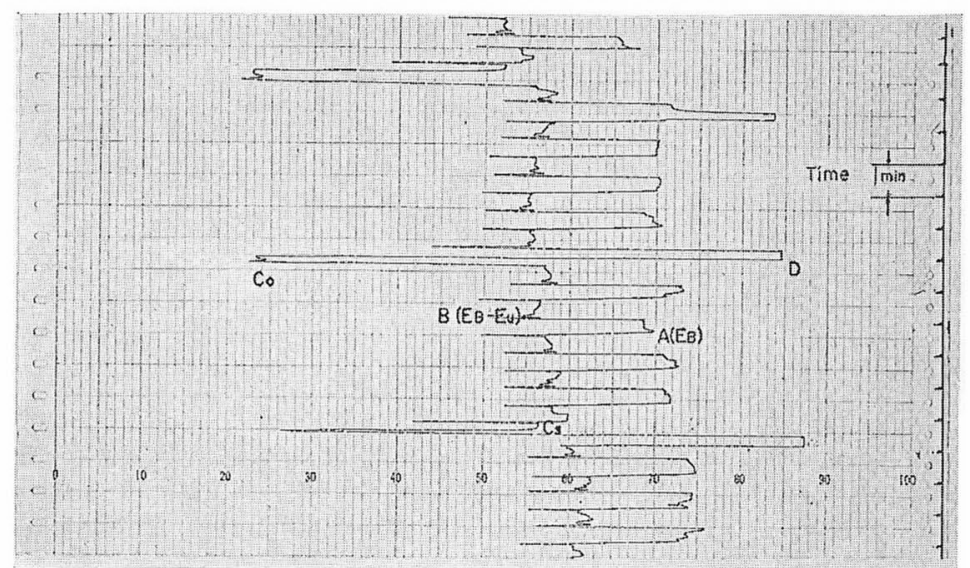

Photo. 3. Observation records.
A: $E_{B}$ (Blue light)
B: $E_{B}-E_{U}$ (Difference between UV and Blue)
C: Standard signal
D: Reference signal (Pressure) 
Fundamentally, these equipments are similar to those used in routine work in the U.S.A.

Photo. 1 shows the appearance of the optical type of ozonesonde, Photo. 2 parts of the sonde and Photo. 3 the observation record.

\section{Evaluation method}

The vertical profile of ozone densities may be obtained by calculating Eq. 8, which can be rewritten as follows:

$$
\log \frac{E_{U}}{E_{B}}=\log A-\alpha \cdot X \cdot \sec z-M \cdot \Delta K_{R}^{*}+\log S_{c}
$$

Then, differentiating Eq. 9, the following equation is given:

$$
\begin{aligned}
\frac{\Delta \log \frac{E_{U}}{E_{B}}}{\Delta h}= & -\alpha \cdot \sec z \cdot \frac{\Delta X}{\Delta h}-\frac{\Delta X \sec z}{\Delta h} \cdot \frac{\partial \alpha}{\partial X \sec z} \cdot X \cdot \sec z \\
& -\frac{\Delta \sec z}{\Delta h} \cdot \alpha \cdot X \\
& -\left\{\Delta K_{R} \frac{\Delta M}{\Delta h}-\frac{\Delta \log S_{c}}{\Delta h}+X \cdot \sec z\left(\frac{\Delta M}{\Delta h} \cdot \frac{\partial \alpha}{\partial M}+\frac{\Delta S_{c}}{\Delta h} \cdot \frac{\partial \alpha}{\partial S_{c}}\right)\right\} .
\end{aligned}
$$

The vertical profile of ozone, $\Delta X \mid \Delta h$, is given by

$$
\begin{aligned}
\frac{\Delta X}{\Delta h}= & \frac{1}{\alpha \cdot \sec z}\left\{\frac{\Delta \log _{E_{B}}^{E_{U}}}{\Delta h}+\frac{\Delta X \cdot \sec z}{\Delta h} \cdot \frac{\Delta \alpha}{\partial X \sec z} \cdot X \cdot \sec z\right. \\
& \left.+\frac{\Delta \sec z}{\Delta h} \cdot \alpha \cdot X\right\}+\Delta_{S c} \frac{\Delta X}{\Delta h}+\varepsilon,
\end{aligned}
$$

where $\Delta_{S c}(\Delta X \mid \Delta h)$ is the correction due to the skylight effect and $\varepsilon$ the correction due to the amount of ozone. The latter can be neglected, because its magnitude is very small.

Before the start of evalaution, it is necessary to get the scattering coefficient, the absorption coefficient and the selective function.

The variables shown in Table 3 are used.

Here, $F_{\lambda}$, shown in Fig. 7 , is experimentally determined. Both $\alpha_{\lambda}$ and $\beta_{\lambda}$ are given by the International Ozone Commission: (IOC Circular No. 04).

$\alpha$ and $\Delta K_{R}$ are derived from Eqs. (4), (4)', (5), (5'), (6), (6)' and (8).

Fig. 13 shows the relation between $\alpha$ and $X \sec z$.

Fig. 14 shows the relation between $\Delta K_{R}$ and $X \sec z$.

In order to evaluate ozone densities with Eq. 11, it is necessary that either the instrument constant, $\mathrm{A}$, or the total amount of ozone densities above the highest 
Table 3.

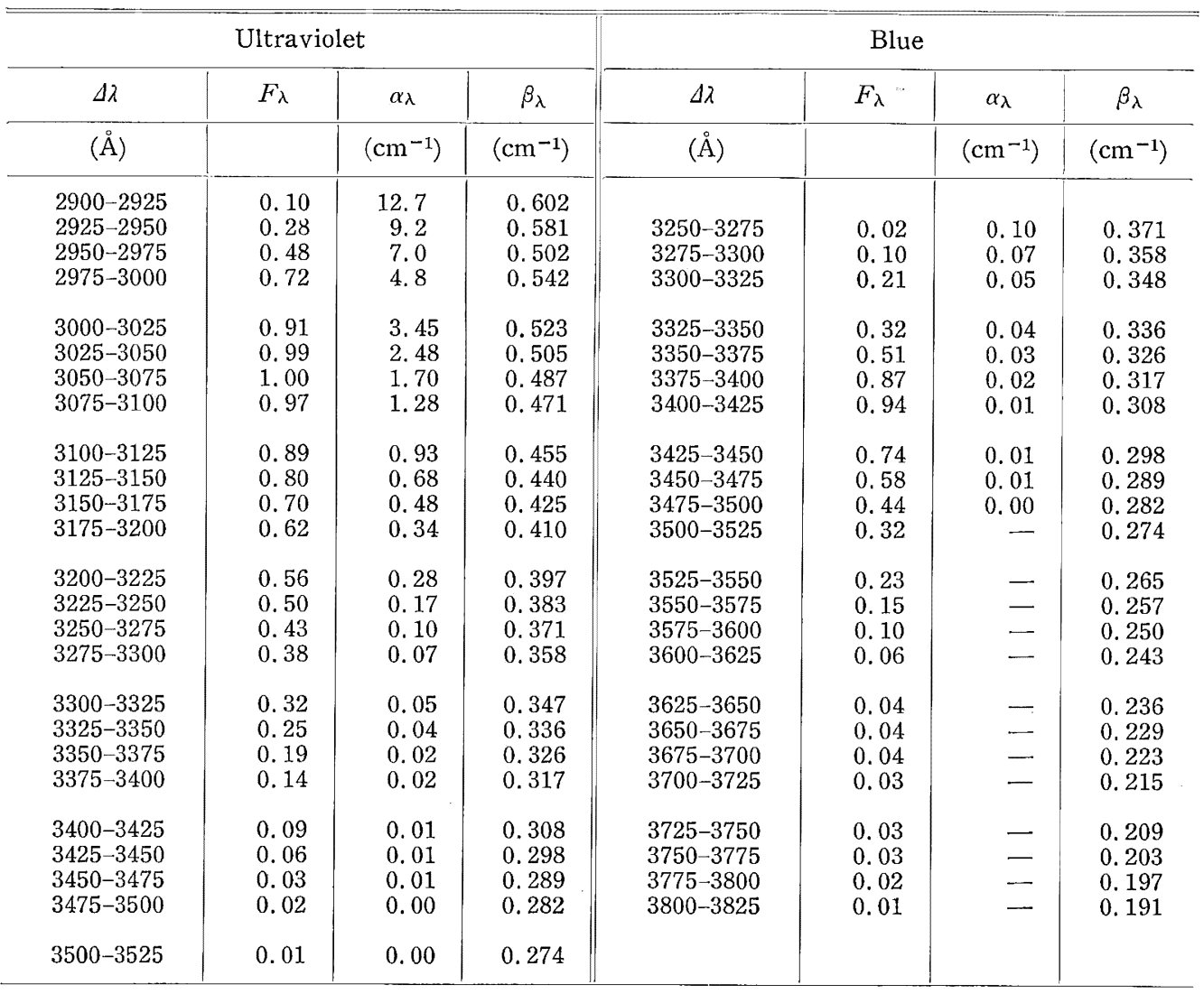

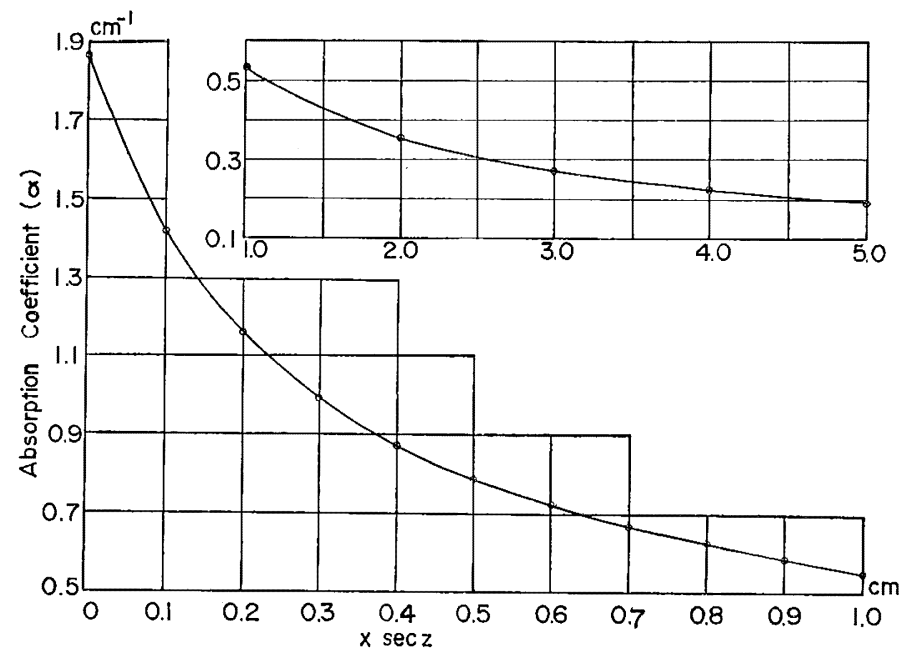

Fig. 13. Relationship between effective absorption coefficient, $\alpha$, and total ozone density above the instrument, $X \sec z$. 


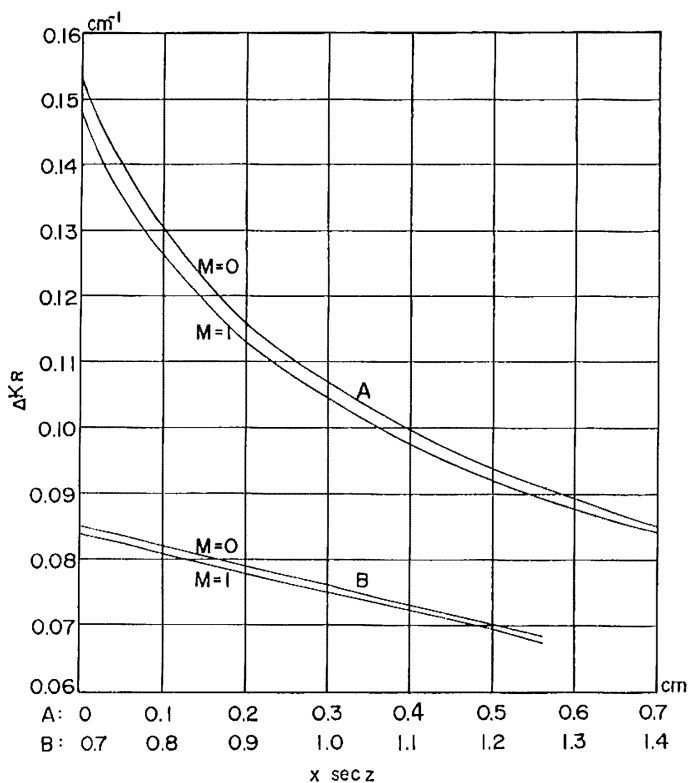

Fig. 14. Relationship between effective Rayleigh scattering factor, $\Delta K_{R}$ and total ozone density above the instrument, $X \sec z$.

level of sounding be well-known in advance of evaluation. Next, the height variation of ozone density is assumed to be known as a first approximation. Based on these results, integrated ozone densities above the instrument, $X$, and then $X \sec z$ can be estimated at various heights. Then, $\alpha$ can be estimated from Fig. 13. Further-

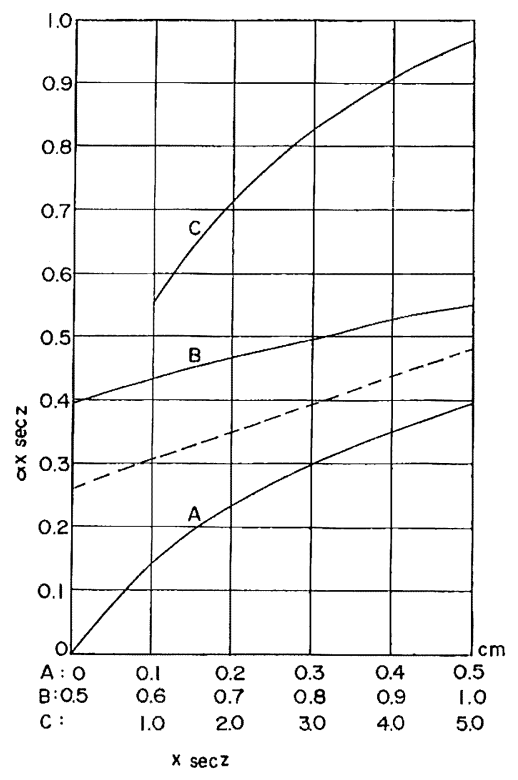

Fig. 15a. Relation between $\alpha X \sec z$ and $X \sec z$.
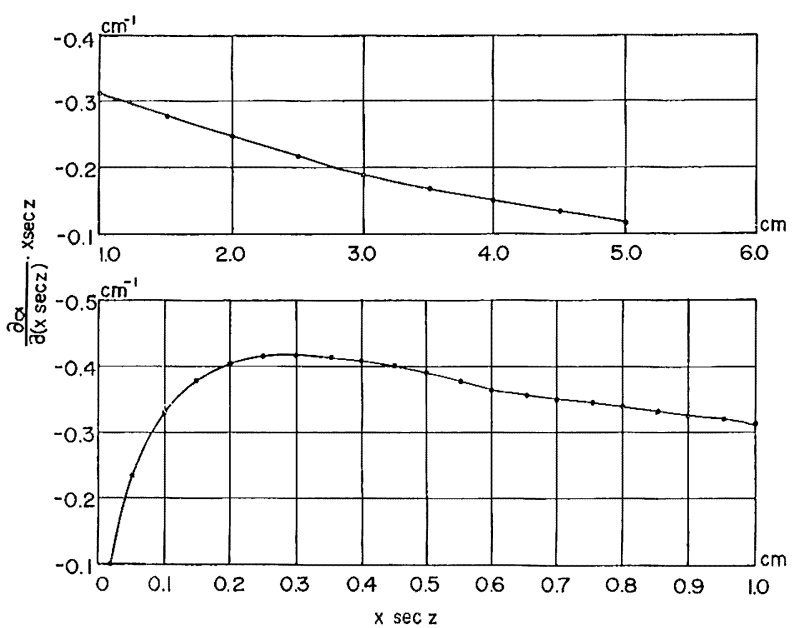
Fig. 15b. Relation between $\frac{\partial \alpha}{\partial X \sec z} \cdot X \sec z$
and $X \sec z$. 
more, the terms $\alpha X \sec z$ and $(\partial \alpha / \alpha X \sec z) X \sec z$ can be obtained from Fig. 15a and Fig. 15b.

As to the term $\Delta_{S c}(\Delta X / \Delta h)$, Kulcke and PAETzold (1961) have already reported experimental values shown in Fig. 16. In our case, they are assumed to be correct. Thus, the second approximation of $\Delta X / \Delta h$ is obtained from Eq. 11 by the aid of the

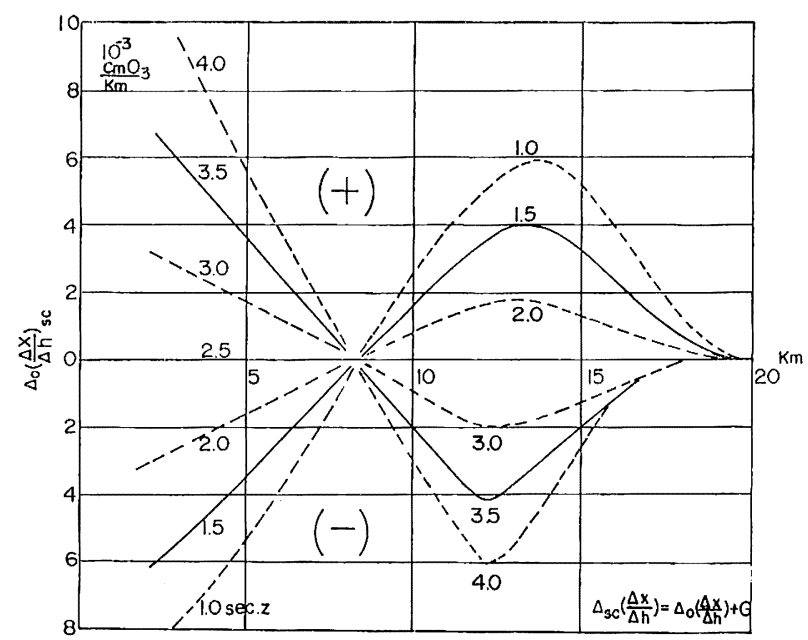

\begin{tabular}{r|l}
\hline$h$ & $G\left(\mathrm{~cm} 0_{3} / \mathrm{km}\right)$ \\
\hline 2 & $-1.5 \times 10^{-3}$ \\
3 & -0.6 \\
4 & +0.3 \\
5 & +1.2 \\
6 & +2.1 \\
7 & +2.9 \\
8 & +3.6 \\
9 & +4.2 \\
10 & +4.2 \\
11 & +3.5 \\
12 & +2.4 \\
13 & +0.8 \\
14 & -1.1 \\
15 & -2.5 \\
16 & -2.9 \\
17 & -2.8 \\
18 & -2.5 \\
19 & -2.2 \\
20 & -1.9 \\
22 & -1.4 \\
24 & -1.0 \\
26 & -0.7 \\
28 & -0.5 \\
30 & -0.3 \\
\hline
\end{tabular}

Fig. 16. Correction chart for the scattering effect of skylight.

above-mentioned graphs. In order to make the approximation better, the same procedure is repeated, where the second approximated value is taken into consideration. Such procedures are continuously carried out to approach the real value.

\section{Flight results}

Fig. 17 shows one example of flight results made in the intercomparison test held in Boulder, Colorado, U.S.A. This shows the comparative results between a Brewer-type ozonesonde (Bubbler type) used in England, a Mast-type, and a Japanese optical-type, which were suspended from the same balloon. On the same day, the so-called Umkehr measurement was done by use of a Dobson-type spectrometer. As shown in Fig. 17, it is to be regretted that the two chemical type sondes show inaccurate results in the layer above the height of $22 \mathrm{~km}$, compared with our instrument.

This suggests that the electrochemical type is in general apt to get the effect of contamination and that much attention should be paid to avoid this unfavorable effect in handling such instruments. It is, however, noticeable that our results are in good agreement with those obtained by the Brewer-type in the layer $13 \sim 20 \mathrm{~km}$ in height.

The total amount evaluated on the assumption of a constant mixing ratio above the height of the balloon burst is less than that obtained by the Umkehr method at 


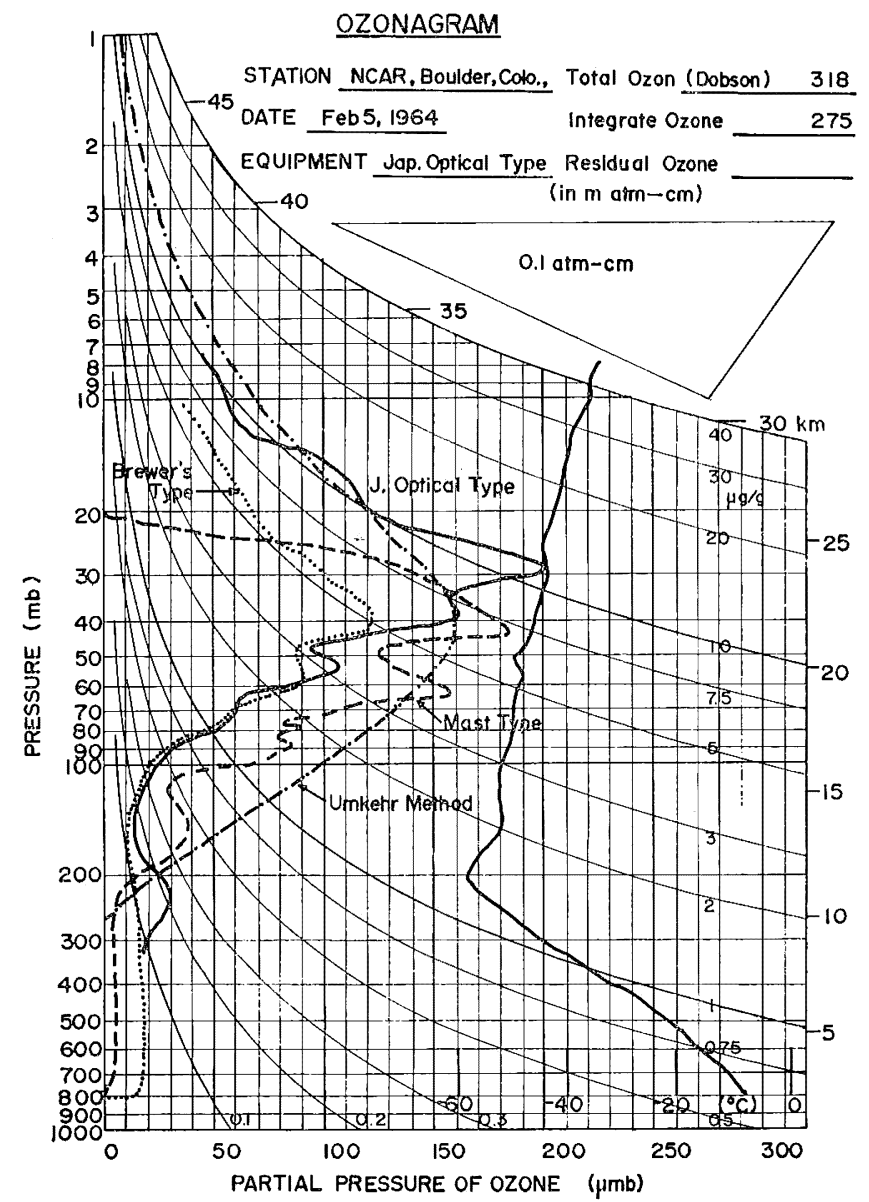

Fig. 17. One of the comparative flight results made at the station, NCAR, in Boulder, U.S.A.

the same time. Its ratio is $87 \%$. This may be due to the estimation of the skylight factor which has not been determined experimentally. By the way, this suggests that the estimated values by KuLCKE and PARTzold (1961) seem to be too small. But it is interesting to note that the vertical profile of ozone densities shows a very similar trace to that of air temperature, though the decrease in air temperature calls for the increase in ozone density.

Fig. 18 shows one of the results obtained in the intercomparison flight test.

The Umkehr measurements show the average trend. Among the Bubbler type, the Mast-type and the optical-type, the same trend was observed at the height of $20 \mathrm{~km}$. Below $17 \mathrm{~km}$, the optical measurements did not coincide with the others. Probably, it may be concluded that the estimation of the effect of skylight is not correct. However, judging from the above-mentioned results, it is noticeable that the correlation between air temperature and ozone density is very high, and the observation with the optical method is relatively reliable above $20 \mathrm{~km}$. 


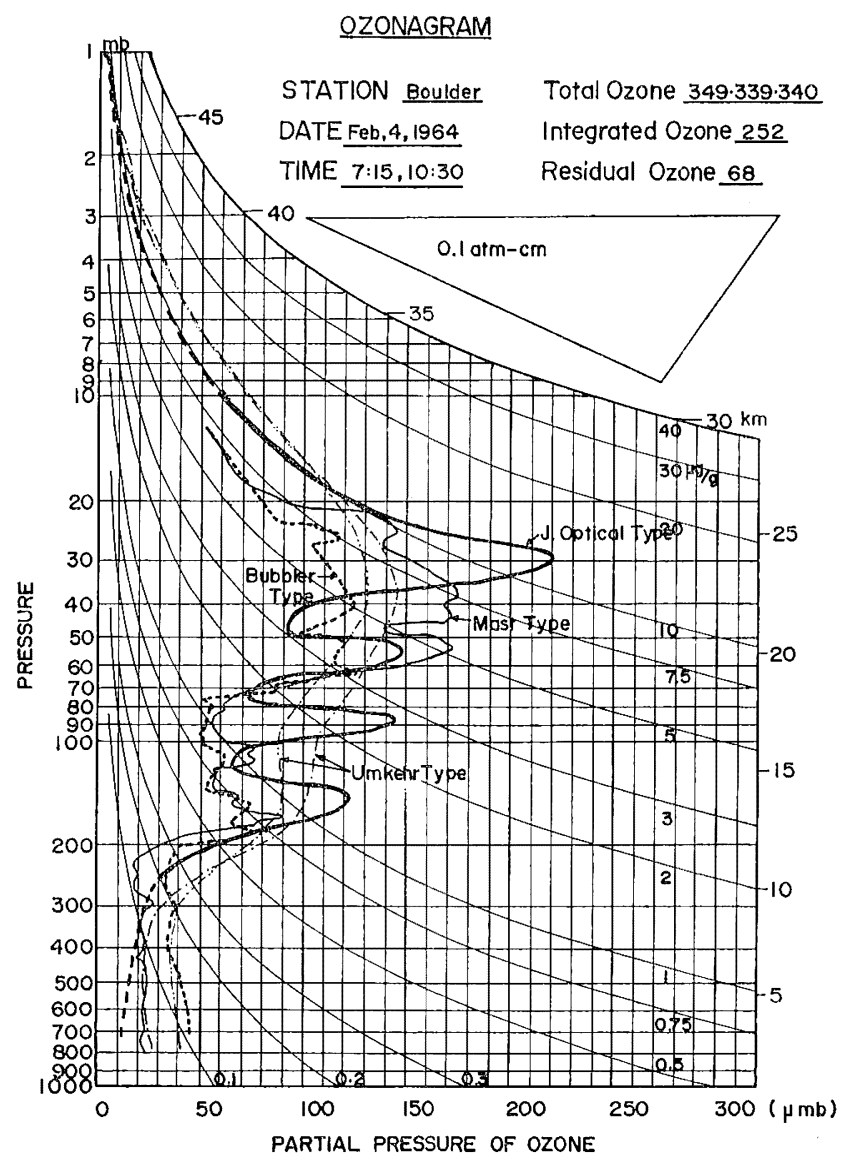

Fig. 18. One of the comparative flight results made at the station, NCAR, in Boulder, U.S.A.

Unfortunately, the measurement with the optical-type ozonesonde is not suitable for giving information on the fine structure of the ozone layer. Because, the effect of skylight remarkably influences the measured values below about $15 \mathrm{~km}$. Besides, the scattered measured values are recorded owing to the swinging of the ozonesonde during its ascent. To make matters worse, the up-and-down motion of the rotating filter frame is accelerated by the motion of the ascending sonde and then the scatter in indication increases more and more. Consequently, much precaution should be taken on the construction of the optical system in order to raise the measuring accuracy. To minimize this unfavorable effect, the sonde should be suspended with a string at least $100 \mathrm{~m}$ in length.

\section{Conclusion}

The details of our ozonesonde have already been given. It might be said that the whole measuring system possesses such merits as accuracy, reliability, low cost and ease of calibration and field use, while it is subject to such unfavourable effects as the up-and-down motion of the rotating filter frame due to the swinging of the 
sonde during flight. Particularly, the effect due to the scattered skylight deals the optical method a fatal blow.

Owing to the restriction due to these demerits, only a mean value of a layer of above $500 \mathrm{~m}$ in depth is given. Therefore, it is very difficult to get information on the fine structure of the lower ozone layer and the vertical transport of ozone into the troposhere. This method, however, brings its merits in full play in the layer above the height of $15 \mathrm{~km}$. In this region, it is far better than any of the other methods. Then, it may be said that the optical method such as ours will be of use in the rocket or satellite instrumentation.

Now, an improved type whose construction is more simple is being used in the routine network. The principle of operation is almost the same.

The measuring error of ours seems to be within $\pm 15 \%$ in comparison with Dobson's spectrometer method. But it will be remarkably improved when it is used for the measurement of the upper ozone layer.

Acknowledgment_— The authors would like to express their hearty thanks to Dr. I. ImAi and Prof. C. Ishri for their kind encouragement. Their gratitude is due to Messrs. N. Arizumi and Y. Sekiguchi for their kind advice given to this work. They also want to thank Mr. T. Shibata, Meiser Elect. Co., and Mr. F. Kitahara for their helpful assistance. It is through Prof. Dr. H.U. Dütsch, Dr. M. Yoshitake and Dr. T. Kitaora that several successful flights in the intercomparison test have been made.

\section{References}

BANCARer J.P. and A. VASSy, 1964: Résultats de quelques sondages récents en France et a Colomb-Béchar, Int. Atm. Ozone Symposium, Aug. Albuquerque, N. M., U. S. A., W. M. O., 28.

Coblenz R. and R. Statr, 1939: Distribution of ozone in the stratosphere, J. Res. Nat. Bur. Standards, 22, 573 .

Kobayashi J., 1965: On various methods of measuring the vertical distribution of atmospheric ozone, Proceedings of the Scientific Session of CIMO-IV, Tokyo, 3-1.

Krueger A.J., 1964: A description of the rocket ozone sonde, Proceedings of the Ozone Symposium, Aug. Albuquerque, N.M., U.S.A., W.M.O., 24.

Kulcke W. and H.K. Paetzolid, 1961: Die Bestimmung der vertikalen Ozonverteilung mit der optischen Ozoneradiosonde, Int. Atm. Ozone Symposium, Arosa, Switzerland.

Kulcke W. and H.K. PaEtzold, 1957: Über eine Radiosonde zur bestimmung der vertikalen Ozoneverteilung, Ann. d. Met., 8, 47. 


\title{
大気オゾンの垂直分布の測定法について（I） 光学式オゾンゾンデ
}

\author{
小林寿太郎，経塚 貢，村松 久实
}

大気オゾンが成層圈, 中閒圈のエネルギー収支, 大気運動を左右する重要な要素であることから，これ の垂直分布の测定手段の開発估 1921 年以降今日飞至っている。

测定法は大別して, 光学的飞行う方法と化学的飞行う方法の 2 つに分けられるが, ここで述べる方法は 前者の部類に属し, その動作原理は, オゾンとより吸収をうける波長 $3050 \AA$, 半檤巾 $200 \AA$, 特よび吸収 を弓けない波長 $3400 \AA ̊$, 半值巾 $100 \AA$ の湍域门のそれぞれの太陽スペクトラム強度を検出し, その強度比 より，機器より上飞ある全オゾン量を算出する方法埮づいている。

機器の特徵は, アクリル樹能, ソーダ硝子といった簡便低廉な素材をもとにした 4 枚のフイルターを用 い透過率の違いを利用して，2つの独立のスペクトラムを選択し，これを安定な情淑伝澾系伝える点に 見出せる。

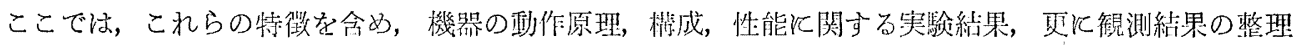
法, 試験飛揚钼測結果とついて総括的な吟味が行なわれている。

なお，スペクトロメーターによるオゾン全量钼測値と峈々 $\pm 15 \%$ 以内で一致しているので，若干の 改善をはかることと, 天空散乱光の補正の仕方を明確化すること飞より, 従来のこの方法飞よる機器飞比 し，確度がよいこと。取报いが簡便であること等の利点が一段と生かされ，オゾン層の探測，特沃オン゙ン 層上部の探測飞最も有利な武器として役立つことが絬諭される。 